\title{
Compliance of the Quality of Educational Services Provided by Vocational Education Institutions with the Labor Market Demand in Qualified Staff under Economic Crisis
}

\author{
LARYSA M. SERGEIEVA ${ }^{1}$, VIRA V. HRIADUSHCHA ${ }^{2}$, GENNADII O. DUBOV ${ }^{3}$, TARAS O. DIDYCH ${ }^{4}$, \\ MARYNA I. SAIENKO ${ }^{5}$ \\ ${ }^{1}$ Department of Vocational and Higher Education, STATE INSTITUTION OF HIGHER EDUCATION “UNIVERSITY OF \\ EDUCATIONAL MANAGEMENT", UKRAINE. E-mail: lar_sergeieva@acu-edu.cc \\ ${ }^{2}$ Department of Technologies of Training, Labor Protection and Design, BILA TSERKVA INSTITUTE OF \\ CONTINUOUS PROFESSIONAL EDUCATION, UKRAINE \\ ${ }^{3}$ Department of Theory and History of Law and State, Institute of Law, TARAS SHEVCHENKO NATIONAL \\ UNIVERSITY OF KYIV, UKRAINE \\ ${ }^{4}$ Department of Theory and History of Law and State, Institute of Law, TARAS SHEVCHENKO NATIONAL \\ UNIVERSITY OF KYIV, UKRAINE \\ ${ }^{5}$ Department of Theory and History of Law and State, DNIPROPETROVSK STATE UNIVERSITY OF INTERNAL \\ AFFAIRS, UKRAINE
}

\begin{abstract}
The article aims to thoroughly study the compliance of the quality of educational services provided by vocational education institutions (hereinafter - VEIs) to the needs of the regional labor market in qualified staff and professional career development. The authors have tested the analysis system of professional success of vocational education graduates and developed technology for evaluating the effectiveness and quality of educational services provided by VEls. By the above, the authors offer to organize activities of Advisory Committees and Professional Councils in the field as an innovative interaction form between vocational education institutions and employers in the professional educational environment.
\end{abstract}

Keywords: Qualified staff; Employers; Stakeholders; Professional educational environment.

JEL Classification: J21, J28 


\title{
Cumplimiento de la Calidad de los Servicios Educativos Prestados por las Instituciones de Formación Profesional con la Demanda del Mercado Laboral en Personal Calificado en Situaciones de Crisis Económica
}

\author{
LARYSA M. SERGEIEVA ${ }^{1}$, VIRA V. HRIADUSHCHA ${ }^{2}$, GENNADII O. DUBOV ${ }^{3}$, TARAS O. DIDYCH ${ }^{4}$, \\ MARYNA I. SAIENKO ${ }^{5}$ \\ ${ }^{1}$ Department of Vocational and Higher Education, STATE INSTITUTION OF HIGHER EDUCATION “UNIVERSITY OF \\ EDUCATIONAL MANAGEMENT", UKRAINE.E-mail: lar_sergeieva@acu-edu.cc \\ ${ }^{2}$ Department of Technologies of Training, Labor Protection and Design, BILA TSERKVA INSTITUTE OF \\ CONTINUOUS PROFESSIONAL EDUCATION, UKRAINE \\ ${ }^{3}$ Department of Theory and History of Law and State, Institute of Law, TARAS SHEVCHENKO NATIONAL \\ UNIVERSITY OF KYIV, UKRAINE \\ ${ }^{4}$ Department of Theory and History of Law and State, Institute of Law, TARAS SHEVCHENKO NATIONAL \\ UNIVERSITY OF KYIV, UKRAINE \\ ${ }^{5}$ Department of Theory and History of Law and State, DNIPROPETROVSK STATE UNIVERSITY OF INTERNAL
} AFFAIRS, UKRAINE

\begin{abstract}
RESUMEN
El artículo tiene como objetivo estudiar en profundidad la adecuación de la calidad de los servicios educativos que brindan las instituciones de educación vocacional (en adelante, VEI) a las necesidades del mercado laboral regional en personal calificado y desarrollo de carrera profesional. Los autores han probado el sistema de análisis del éxito profesional de los graduados de educación vocacional y han desarrollado tecnología para evaluar la efectividad y la calidad de los servicios educativos brindados por los VEI. Por lo anterior, los autores ofrecen organizar actividades de Comités Asesores y Consejos Profesionales en el campo como una forma de interacción innovadora entre las instituciones de educación vocacional y los empleadores en el entorno educativo profesional.
\end{abstract}

Palabras clave: Personal calificado; Empleadores; Stakeholders; Ambiente educativo profesional.

Clasificación JEL: J21, J28 


\section{Introduction}

Since Ukraine changes over to the latest development model, where the main source of economic growth is human capital development, it requires a radical revision of methods and mechanisms of the labor market regulation. It will ensure the redistribution of employment by activity and sector of the economy. The significant importance has both the level and quality of specialist training and their compliance with the labor market needs, i.e., the balance of supply and demand for staff.

Although the Verkhovna Rada of Ukraine has approved the Strategy of Innovation Development of Ukraine for 2010-2020 in the Environment of Globalization Challenges by its Resolution of October 21, 2010, No. 2632-VI, there is a significant occupational imbalance in the current labor market of Ukraine. The country still does not apply a comprehensive approach to forecasting the needs of productive and non-productive spheres in skilled workers, taking into account the national economic structure (Verkhovna Rada of Ukraine, 2010).

There is no working system to comprehensively assess the ratio of supply and demand in the labor market of Ukraine, and the measures to equalize the occupational imbalance are impossible to take due to this problem. An equally serious negative phenomenon in the labor market was the outflow of young, skilled workers, which led to a sharp increase in aging. The systemic difficulties the entire vocational education system in Ukraine has experienced can also include Russian military intervention and, as a result, the occupation of part of the region's territory. Thus, having studied the vocational education development in the region at this stage, we can both get an idea of its state and forecast further development (Kozlovskyi et al., 2019).

The process of training highly qualified workers requires optimization and extending basic knowledge; differentiation and integration of the content of education in the main areas of future professional activity; strengthening professional orientation; development of non-standard and creative thinking and research skills (Sydorenko et al., 2020). This training can be carried out on the basis of $\mathrm{VEI}$ if there are reasonable intensifications of the educational process, deep integration of education programs in several professions, and the use of information and pedagogical technologies.

The following sectors show the greatest demand for labor: processing industries; trade; repair of cars and household and personal items; statecraft; transport and communication. Since 2003, there has been an increase in supply, and most job offers are in the following spheres: trade, repair of cars and household and personal items, agriculture, hunting, and forestry, processing industry, transport, and communications (Kosiv, 2003).

The prediction of a need can rest on interrelated forecasts of population and employment as well as demographic, economic, technical, social forecasts, and so on. Analysis of the labor market development forecast is an important tool for the active interaction of VEls with social partners. The forecast data allow tracking structural changes in the labor force by occupations due to the intersectoral distribution of employees. They also are needed to provide directions for vocational education development, taking into account the industries' demand for qualified staff.

Research data show that from $1 / 3$ to $2 / 3$ of laid-off workers change their profession, which signifies a need for an organized system of staff retraining. In contrast to the training of new employees, retraining is the acquisition of a new profession by employees. In addition, professional knowledge tends to age rapidly in modern conditions. Previously, acquired professional knowledge and skills were enough for the whole working life. However, the time of turnover of a profession has been significantly reduced during the Fourth Industrial Revolution and does not coincide with the individual employment period in most cases (Schwab, 2019; Yaroshenko et al., 2018).

The introduction of integrated mechanization, automation, computerization, and new communication systems has a diverse impact on a human's work, role, and significance in public production, which further affects the determination of requirements for the quality of labor potential. There is a transformation of the employee model, and qualification acquires more significance, and together with the organization and motivation of work, they become a crucial link in increasing 
competitiveness. The basis for skilled employee training in terms of occupations should be the current, short-term, and long-term need for staff in all areas of economic activity (Word and deed, 2021).

According to the research data of the Institute of Vocational Education of the National Academy of Educational Sciences of Ukraine (2021), educational institutions that provide vocational training do not take into account the realities of the labor market. Today, the employer puts new demands on their employees, and they are as follows: active participation in the production growth at almost every workplace; ensuring the high quality of products that are fast-changing and technologically complicated; improvement of production methods, independence in solving professional problems, critical and creative thinking; adaptive flexibility in changing life situations, independence in knowledge acquisition, their practical application for solving various problems; ability to generate new ideas, the creativity of thinking; media literacy; sociability, including different social groups and teamwork skills; ability to prevent conflicts or skillfully overcome them. Since the existing vocational training system aims at developing only professional qualities, it cannot satisfy the demands of modern society. The new quality of training with different levels of vocational education requires other criteria for its evaluation (Anishchenko et al., 2012).

To ensure the development of the economy and social sphere at the new scientific and technical level, there is a need to take the following measure: review the nomenclature of specialties and professions and determine the list of professions that require deep professional knowledge; introduce centralized forms of employees retraining, laid-off due to closed industries; develop subprograms for the creation and functioning of career centers in the cities and regions; ensure compliance of the quality of labor force with the production and technical potential of the region. According to the medium-term forecast of demands for experts and staff in the labor market for 2020-2024, although the labor market needs for qualified staff grow, there is a significant decrease in regional orders in vocational education institutions. The amount of training of skilled employees at the expense of local budgets decreased by $16 \%$ during 2016-2019.

High requirements for the quality of the labor force need an adequate increase in wages, the introduction of additional material incentives, and the growth of total per capita income. Researchers believe Ukraine should soon expect an increase in the imbalance between supply and demand in the level of education in the labor market. If we consider the slow changes in the economic needs for professional qualifications and the current volume of admissions to HEls, the gap between the supply and demand of skilled employees in specialties can only increase. On the other hand, the share of people with vocational education will remain more or less stable among the economically active population. Thus, the imbalance is expected to grow mainly due to an increase in the number of people with higher education among the economically active population (Institute of Vocational Education..., 2021).

For HEls today, it is important to ensure customers' achievement of educational levels and acquisition of competencies needed for their competitiveness in the regional labor market but not just educate professions, which are in demand in the labor market. In this case, the quality of the "product of education" will meet the requirements of the "consumer" - the labor market and the employer.

\section{Theoretical overview}

Under the influence of globalization and transformation processes, the education sector in Ukraine undergoes modernization. The Cabinet of Ministers of Ukraine adopted the Concept for the Implementation of the National Policy in the field of Vocational Education, "Modern Vocational Education," for the period to 2027 (Cabinet of Ministers of Ukraine, 2019). According to the above document, this process is aimed at creating the necessary conditions for innovative development of vocational training of various population categories, in particular in vocational (vocational and technical) education institutions (hereinafter - VEI) of various types, forms of ownership, and subordination, in the workplace, etc. Among others, there is an aim to ensure high-quality professional training of skilled employees for industries, small and medium enterprises, taking into account the 
needs of the regional labor market. Today we see dozens of new professions that one could not have imagined 10 years ago. Existing and future professions reflect our world - diverse, mobile, interesting, with many opportunities for each person, which correspond to his or her abilities, talents, knowledge, competencies, skills, and ability to adapt to rapidly changing conditions (Anishchenko et al., 2012).

In The Future of Jobs Report, 2020, the World Economic Forum in Davos (hereinafter - WEF) identifies active learning and learning strategies, analytical thinking, and innovation as one of the most important skills for a successful career in a changing world. The WEF believes these skills will help people to adapt to a changing world. They estimate the division of labor between people and machines may lead to the replacement of 85 million jobs by 2025. At the same time, there may be 97 million new roles in 15 sectors of the economy, better adapted to the new division of labor between people and machines (World Economic Forum, 2020).

According to the State Statistics Service of Ukraine, in 2018, the young population aged 15-34 was about $40 \%$ of the total number of unemployed jobseekers for more than 12 months (State Statistics Service, 2021). In recent years, there has been a tendency to increase the number of young people who have been unemployed for more than a year. Moreover, some of them are forced to remain in a state of long-term unemployment from the very beginning of their working life. In 2018, among graduates from higher education institutions (hereinafter - HEls), who received the services of the public employment service, $33 \%$ received a degree in the field of social sciences, business, and law, $13 \%$ - in engineering specialties, $12 \%$ - health care, $11 \%$ - humanities and arts.

Today, $44 \%$ of freelance graduates work in specialties they have not trained in, and $29 \%$ - in specialties only partially related to the received ones (Ukrinform, 2019). The main trends in world vocational education of the XXI century are huge competition among specialists and educational institutions, the globalization of information exchange, technological and information revolution, the rapid aging of knowledge.

The formation of labor potential and its development prospects are crucial for the future economy of Ukraine and the creation of conditions for its transition to an innovative model. At the same time, the level and quality of labor potential are key for ensuring the competitiveness of the country's economy, which is the basis of stability in society. Labor potential functioning in Ukraine takes place under the economic crisis and social contradictions in society. The demographic features of labor potential reproduction characterize the natural basis for its building (Carpio et al., 2017). Economic and social factors indicate unemployment problems, the spread of illegal employment, the decline of national intellectual and educational potential, a significant income stratification in the population.

Traditionally, the labor market means a system of relationships between buyers (employers) and sellers (able-bodied population) of the labor force, which contribute to the placement of human resources in the social labor division system under the laws of commodity production and circulation (Sydorenko, 2020a). The labor market also includes a seller, buyer, product, and price. A job seeker is a seller who offers his or her knowledge, skills, abilities. A buyer is an employer. The law of supply and demand also applies in the labor market. The ideal option is when demand is equal to supply. When supply exceeds demand, there is unemployment or staff shortage.

Regarding an employer (a job owner), the state policy in the labor market aims at attracting a labor force with a certain quality, thus creating the preconditions for a combination of production factors (Sydorenko, 2020b). The state policy is also focused on selecting jobs for job seekers corresponding to their professional qualifications, demographics, and other characteristics. The purposes of state policy in the labor market also involve the following: providing training services for the unemployed (professional retraining and advanced training); taking measures to ensure their maintenance (public and other temporary work); control over the unemployment rate, etc.

In foreign and domestic sources, the term "staff" is often identified with only part of the workers, namely specialists or highly qualified employees with work experience at a particular company (the UN General Assembly, 2015). The term "personnel" is more appropriate at the level of the organization as it defines the workforce of an organization, working for hire and characterized by certain features. 
The main ones are: labor relations with an employer, as a rule, are documented by employment contracts; possession of certain qualitative characteristics, a combination of personal and organizational goals (Krushelnytska \& Melnychuk, 2005). The authors offer to assess the labor market conditions (Table 1 ) by such indicators as the average monthly nominal wage, compensation of employees, the number of employed and unemployed.

Table 1. Dynamics of labor market indicators in Ukraine

\begin{tabular}{|c|c|c|c|c|}
\hline Years & $\begin{array}{c}\text { Average monthly } \\
\text { nominal wage, } \\
\text { UAH }\end{array}$ & $\begin{array}{c}\text { Compensation of } \\
\text { employees, UAH } \\
\text { billion }\end{array}$ & $\begin{array}{c}\text { Number of } \\
\text { employees, } \\
\text { million people }\end{array}$ & $\begin{array}{c}\text { Number of } \\
\text { unemployed, } \\
\text { thousand people }\end{array}$ \\
\hline 2010 & 2239 & 540.651 & 20.266 & 1785.6 \\
\hline 2011 & 2633 & 636.722 & 20.3422 & 1732.7 \\
\hline 2012 & 3026 & 736.495 & 20.3543 & 1657.2 \\
\hline 2013 & 3265 & 763.187 & 20.4041 & 1576.5 \\
\hline 2014 & 3480 & 734.943 & 18.0733 & 1847.6 \\
\hline 2015 & 4195 & 777.646 & 16.4432 & 1654.7 \\
\hline 2016 & 5183 & 873.829 & 16.2796 & 1678.2 \\
\hline 2017 & 7104 & 956.234 & 16.4564 & 1698.0 \\
\hline 2018 & 8105 & 1002.345 & 16.6745 & 1705.5 \\
\hline 2019 & 8958 & 1134.675 & 16.8567 & 1719.8 \\
\hline
\end{tabular}

Source: compiled by authors.

Thus, the average monthly nominal wage and the level of compensation of employees have increased during the studied years, and that is a positive trend. However, the number of employed decreased and the number of unemployed increased, which is a negative social phenomenon. There was a positive trend in reducing injuries. Regarding the urban and rural population, its number does not reflect environmental trends.

Considering the labor market in the agricultural sector, its indicators can be the number of employed and unemployed, the level of compensation of employees, personnel costs, the average monthly nominal wage (Table 2). As you can see, there has been a simultaneous decrease in the number of employed and unemployed in Ukraine during the studied years, which is a positive trend. In 2014-2015, an increase in the level of compensation of employees and the average monthly nominal wage was another positive trend.

Table 2. Parameters of the labor market in the agricultural sector of Ukraine

\begin{tabular}{|c|c|c|c|c|c|c|}
\hline Years & $\begin{array}{c}\text { Number of } \\
\text { employees, } \\
\text { million } \\
\text { people }\end{array}$ & $\begin{array}{c}\text { Number of } \\
\text { unemployed, } \\
\text { thousand } \\
\text { people }\end{array}$ & $\begin{array}{c}\text { Compensation } \\
\text { of employees, } \\
\text { UAH billion }\end{array}$ & $\begin{array}{c}\text { Personnel } \\
\text { costs, UAH } \\
\text { million }\end{array}$ & $\begin{array}{c}\text { Average } \\
\text { monthly } \\
\text { nominal } \\
\text { wage, UAH }\end{array}$ & $\begin{array}{c}\text { Benefits- } \\
\text { related } \\
\text { deduction, } \\
\text { UAH million }\end{array}$ \\
\hline 2010 & 3.0945 & 117 & 17.896 & 12370.3 & 1430 & 3736.2 \\
\hline 2011 & 3.3938 & 116 & 22.755 & 15449.1 & 1853 & 4716.5 \\
\hline 2012 & 3,496 & 115 & 26.739 & 19506 & 3026 & 5786.7 \\
\hline 2013 & 3.5775 & 112.6 & 30.745 & 23537.3 & 2272 & 6281.6 \\
\hline 2014 & 3.0914 & 112.6 & 31.274 & 25524.5 & 2476 & 6789.3 \\
\hline 2015 & 2.8706 & 102.9 & 35.131 & 28856.1 & 3140 & 7332.9 \\
\hline 2016 & 2.8665 & 90.9 & 40.834 & 33407.6 & 3916 & 6014.6 \\
\hline 2017 & 2.8607 & 92.1 & 45.000 & 44266.8 & 5761 & 7897.3 \\
\hline
\end{tabular}

Source: compiled by authors.

The number of employed and unemployed, the level of compensation of employees, personnel costs, and the average monthly nominal wage can indicate the labor market conditions in the extractive sector (Table 3). With the specified years, the number of employed and unemployed, as you can see, has simultaneously decreased in the sector, which is a positive trend. There was an increase 
in the level of employees' compensations in 2010-2013. Although it decreased significantly in 20142015 , its gradual growth has begun since 2016. At the same time, the average monthly nominal wage increased in this industry. The trend had an opposite nature since the level of compensation of employees decreased while increasing compensation levels of owners.

Table 3. Parameters of the labor market in the extractive sector of Ukraine

\begin{tabular}{|c|c|c|c|c|c|c|}
\hline Years & $\begin{array}{c}\text { Number of } \\
\text { employees, } \\
\text { thousand } \\
\text { people }\end{array}$ & $\begin{array}{c}\text { Number of } \\
\text { unemployed, } \\
\text { thousand } \\
\text { people }\end{array}$ & $\begin{array}{c}\text { Compensation } \\
\text { of employes, } \\
\text { UAH billion }\end{array}$ & $\begin{array}{c}\text { Personnel } \\
\text { costs, } \\
\text { UAH } \\
\text { million }\end{array}$ & $\begin{array}{c}\text { Average } \\
\text { monthly } \\
\text { nominal } \\
\text { wage, UAH }\end{array}$ & $\begin{array}{c}\text { Benefits- } \\
\text { related } \\
\text { deduction, } \\
\text { UAH million }\end{array}$ \\
\hline 2010 & 448.5 & 5.9 & 34.536 & 19379.9 & 3539 & 8769.3 \\
\hline 2011 & 449.6 & 5.8 & 40.983 & 22672.8 & 4370 & 10307.2 \\
\hline 2012 & 439.9 & 5.7 & 44.739 & 27506.9 & 4881 & 12113.3 \\
\hline 2013 & 429.2 & 5.6 & 49.193 & 29126.7 & 5289 & 12649.5 \\
\hline 2014 & 359.8 & 5.4 & 34.726 & 29532.7 & 5445 & 8629.7 \\
\hline 2015 & 261.4 & 5.1 & 34.219 & 29372.0 & 6164 & 8208.4 \\
\hline 2016 & 239.1 & 4.2 & 39.644 & 30370.2 & 7462 & 5344.2 \\
\hline 2017 & 220.5 & 3.4 & 45.000 & 35521.3 & 9704 & 6039.8 \\
\hline
\end{tabular}

Source: compiled by authors.

The labor market indicators in the manufacturing sector can include the number of employed and unemployed, the level of compensation of employees, personnel costs, the average monthly nominal wage (Table 4).

Table 4. Parameters of the labor market of the processing industry of Ukraine

\begin{tabular}{|c|c|c|c|c|c|c|}
\hline Years & $\begin{array}{c}\text { Number of } \\
\text { employees, } \\
\text { thousand } \\
\text { people }\end{array}$ & $\begin{array}{c}\text { Number of } \\
\text { unemployed, } \\
\text { thousand } \\
\text { people }\end{array}$ & $\begin{array}{c}\text { Compensation } \\
\text { of employees, } \\
\text { UAH billion }\end{array}$ & $\begin{array}{c}\text { Personnel } \\
\text { costs, } \\
\text { UAH } \\
\text { billion }\end{array}$ & $\begin{array}{c}\text { Average } \\
\text { monthly } \\
\text { nominal wage, } \\
\text { UAH }\end{array}$ & $\begin{array}{c}\text { Benefits- } \\
\text { related } \\
\text { deduction, } \\
\text { UAH million }\end{array}$ \\
\hline 2010 & 1919.9 & 74.8 & 95.678 & 68.9802 & 2288 & 18574.8 \\
\hline 2011 & 1879.7 & 75 & 115.224 & 82.9553 & 2771 & 22473.4 \\
\hline 2012 & 2321.6 & 75.1 & 128.708 & 96.5765 & 3097 & 25877.7 \\
\hline 2013 & 2275.5 & 75.2 & 118.313 & 100.2493 & 3311 & 26817 \\
\hline 2014 & 2022.2 & 75.3 & 123.632 & 96.1224 & 3570 & 25688.6 \\
\hline 2015 & 1839.3 & 60.9 & 132.968 & 104.7857 & 4477 & 25954.4 \\
\hline 2016 & 1791.7 & 45.3 & 137.331 & 113.3269 & 5543 & 20030.4 \\
\hline 2017 & 1774.9 & 42.2. & 142.000 & 149.6671 & 7299 & 26184.3 \\
\hline
\end{tabular}

Source: compiled by authors.

As you can see, the number of employed and unemployed has simultaneously decreased in Ukraine during the studied years. The level of compensations of employees and the average monthly nominal wage increased in 2010-2017. All the above indicates a positive trend.

The pandemic caused by the outbreak of COVID-19 has become a serious test for the entire world economy. The experts from the International Labor Organization consider the Crisis of 2020 is the worst over the past few decades. The situation in the labor market of our country also remains difficult (State Institute for Family and Youth Policy, 2020). According to the State Statistics Service of Ukraine, GDP fell by $4.0 \%$ for 2020 . The results of the economic downfall were a drop in employment and a rise in unemployment. In 2020, the number of employed population aged from 15 to 70 decreased by 663 thousand people compared to 2019 and amounted to 15.9 million people. The employment rate decreased from 58.2\% to 56.2\% (State Statistics Service, 2021). The methodology of the International Labor Organization showed that the number of unemployed increased in 2020 by 187 thousand 
compared to 2019 and amounted to 1.7 million people. The unemployment rate increased from $8.2 \%$ to $9.5 \%$ of the labor force.

The average reporting quantity of full-time employees in Ukraine was 7.3 million in December 2020, which is 37 thousand people less than in December 2019. The reduction was observed in half of the economic activities. The number of full-time employees in the industry was 1.8 million, which is 60 thousand less than in December 2019. In particular, the number of workers decreased by 7 thousand in the mining and quarrying sector, by 8 thousand - in metallurgical production, manufacture of fabricated metal products, except machinery and equipment, by 26 thousand - in mechanical engineering.

The highest employment rate was observed in the city of Kyiv (61.9\%), Kharkiv (60.5\%), Dnipropetrovsk (58.3\%), and Kyiv (58.1\%) oblasts, while Donetsk (49.5\%) and Volyn (49.1\%) oblasts had the lowest employment rate. The employment rate decreased among citizens of all ages, but the exception is people aged 50-59, among whom this rate increased from $68.1 \%$ to $68.5 \%$. People aged from 30 to 50 represent the highest employment rate (from $74.7 \%$ to $76.8 \%$ ), and the lowest is observed among those of 60 to $70(13.6 \%)$ and 15 to $24(25.9 \%)$ years old. A low rate of youth employment is due to their studying and non-belonging to the labor force.

The reduction in the employment volume and rate touched both urban settlements and rural areas, women and men (State Statistics Service, 2021). In urban settlements, the number of employed people from 15 to 70 years old decreased by 414 thousand ( 11.0 million people), and the employment rate fell from $59.4 \%$ to $57.5 \%$. The employed population in rural areas was 213 thousand less in number (5.0 million people), and the employment rate decreased from $56.2 \%$ to $54.4 \%$. The number of women from 15 to 70 years old decreased among the employed population by 304 thousand (to 7.7 million people), and the employment rate was down by $1.7 \%$. Among men, the employed population decreased by 323 thousand (to 8.3 million people), and the employment rate fell from $64.1 \%$ to $62.0 \%$. In the third quarter of 2020, the number of employed people aged $15-70$ decreased by 1.0 million compared to the third quarter of 2019 and amounted to 15.9 million people. The employment rate of the population aged from 15 to 70 was down by $3.2 \%$.

According to the ILO methodology, the unemployed population from 15 to 70 years old amounted to 1.6 million people for the nine months of 2020. This is 182 thousand people more compared to the nine months of 2019. The unemployment rate (according to the ILO methodology) among the population from 15 to 70 years old increased from $8.1 \%$ to $9.3 \%$. The growth of unemployment characterized all regions. TThe lowest unemployment rate was observed in Kharkiv (5.9\%), Kyiv (6.8\%), Odesa (6.9\%) oblasts, and the city of Kyiv (6.6\%), while the highest one was marked in Kirovohrad (12.5\%), Volyn (12.4\%), Donetsk (14.7\%), and Luhansk (15.4\%) oblasts. The growth of unemployment has touched citizens of all ages. There was the lowest unemployment rate $(8.0 \%)$ among people from 30 to 34 years old. However, this figure was $19.3 \%$ of the labor force among the youth under 25 (twice as high as among the whole population) (State Institute for Family and Youth Policy, 2020). We should note that the unemployment rate increased from $6.3 \%$ to $7.6 \%$ in the European Union, especially among the youth under the age of 25 , since this figure grew up from $14.5 \%$ to $17.4 \%$ of the labor force. The unemployment volume and rate went up both in urban settlements and rural areas, among women and men. In urban settlements, the number of unemployed from 15 to 70 years old increased by 101 thousand (to 1,079 thousand people), and the unemployment rate grew from $7.9 \%$ to $8.9 \%$.

The number of unemployed increased by 81 thousand people (up to 564 thousand) in rural areas, the unemployment rate rose from $8.6 \%$ to $10.2 \%$ of the labor force (State Statistics Service, 2021). The number of women increased among the unemployed population by 94 thousand (to 748 thousand people), and the unemployment rate was up from $7.6 \%$ to $8.9 \%$ of the labor force. Among men, the number of unemployed increased by 88 thousand (up to 895 thousand people), and the unemployment rate rose from $8.5 \%$ to $9.7 \%$. At the same time, there are significant regional disparities in labor compensation. Only employees in the city of Kyiv (17.6 thousand UAH), Donetsk (12.8 thousand $\mathrm{UAH}$ ), and Kyiv (12.2 thousand $\mathrm{UAH}$ ) oblasts received above-average wages in the country. Regarding economic activities, the highest wages were in the following sectors: air transport (22 
thousand UAH); finance and insurance (20 thousand $\mathrm{UAH}$ ); information and telecommunications (20 thousand $\mathrm{UAH}$ ). The employees from temporary accommodation and catering, postal, and courier sectors got the lowest wages (6-7 thousand UAH). The highest wages were in the following sectors of industrial activity: basic pharmaceutical products manufacturing ( 21 thousand $\mathrm{UAH}$ ); extractive (17 thousand UAH); the supply of electricity, gas, steam, and air conditioning (16 thousand UAH); refined products manufacturing (16 thousand $\mathrm{UAH}$ ). In terms of the lowest wages, they were in textile, clothing, and leather manufactures ( 8 thousand $\mathrm{UAH}$ ). The average wage was 13 thousand UAH in industrial activities.

As reported by the State Employment Center of Ukraine (2021), 427 thousand unemployed have been registered with the State Employment Service as of April 9, 2021. This is $13 \%$ more than on April 9 last year. According to the National Bank of Ukraine, 400-500 thousand Ukrainian citizens, who worked abroad, returned to the country due to the pandemic in 2020. However, it is difficult to say how much they have increased demand in the labor market. The employment service does not keep separate records of such citizens when applying to employment centers. Under the current legislation, all citizens who apply to the State Employment Service receive their services on general grounds.

During 2020, the services of the State Employment Service more than 1.2 million unemployed citizens took advantage. 210 thousand of them previously worked at industrial enterprises. Employers meanwhile informed employment centers there are 829 thousand job offers, 198 thousand (or 24\%) of which are at industrial enterprises. In particular, mining and quarrying enterprises announced 12 thousand job offers, and metallurgical production and the manufacture of fabricated metal products, except machinery and equipment, offered the same number. There were 25 thousand job offers from mechanical engineering enterprises. In general, the Ukrainian employers submitted 324 thousand (or $28 \%$ ) fewer job offers to the State Employment Service. Mining and quarrying enterprises decreased the number of job offers by 6 thousand, or 31\%; metallurgical production and the manufacture of fabricated metal products, except machinery and equipment - by 9 thousand, or 43\%; mechanical engineering enterprises - by 14 thousand, or 34\% (State Employment Center of Ukraine, 2021).

As of April 1, 2021, six unemployed applied for one vacant job on average in Ukraine, i.e., one person more than a year earlier. The workload per vacant job in the industry was 5 unemployed (as of April 2020 - 3 people). 4 unemployed applied for one vacant job in the mining and quarrying sector, while there were three of them a year earlier. There were 4 unemployed per vacant job in sectors of metallurgical production and the manufacture of fabricated metal products, except machinery and equipment, the same situation was last year. As for the mechanical engineering sector, there were 5 unemployed per vacant job compared to three in the previous year.

Employers in the mining industry, metallurgy, and mechanical engineering show the greatest demand for workers skilled in tools, maintenance, equipment operating, and machinery. In particular, they are representatives of the following professions: hot metal mill operator; driver; mine worker; electric welder; electrician; engineer; dozer operator; operator of rock removing machines; mounter; machine operator with software control; sinker; locksmith; sling operator; turner; manual and machine molder; milling-machine operator; grinder, etc. In total, the industry needs five and a half thousand workers.

There is a survey on the State Employment Center of Ukraine (2021) website aimed at preparing information on recruitment needs for 2021. Since February 1, it also surveys employers on workforce needs. As of March 25, 2021, 3,000 employers reported a need for 21,000 employees. Among them are 600 industrial enterprises, which need 5,500 workers. In particular, the distribution of demand for workers by a separate sector of the industry is as follows: mining industry - 640 people (mine worker, pick hammer operator, timberman, mounter, electric and gas welder); metallurgical production and the manufacture of fabricated metal products, except machinery and equipment - 302 people (machine operator with software control, one who polishes with emery, wiredrawer, turner, loader driver, etcher, hot galvanizer, enameler); mechanical engineering - 368 people (design engineer, blacksmith and punch press operator, metal mender, electric welder, rolling stock repairman, electric welder, metal structures repairman, crane driver). As we can see, despite the difficult situation in the 
labor market of Ukraine, the vocational education system has all development opportunities since the labor demand remains.

The following ways can contribute to the replenishment of the labor market with qualified staff:

- provide affordable and free complete general secondary education in national and municipal vocational education institutions and opportunities to obtain quality knowledge in the system of vocational education institutions;

- promote professional self-determination and effective adaptation of young people to the conditions of a market economy; develop the educational services market;

- strengthen the orientation of the system of vocational education and training, pre-tertiary vocational education, higher and postgraduate education on training, retraining, and advanced training to comply with regional labor market needs;

- create conditions for vocational and higher education to be available for all social groups by training workers and specialists by state order;

- build a system for lifelong learning through the implementation of gradual training, create conditions for self-education;

- improve the legal framework for vocational in-service training of personnel under their social development programs, provide these enterprises with state support;

- integration of vocational, higher, and postgraduate education in Ukraine into the international educational system.

Thus, there is a need to develop a mechanism for compliance of the educational services market with the labor market needs, taking into account the balance of supply and demand for labor. Moreover, vocational in-service training of personnel and training of unemployed citizens should be developed. It is needed to apply flexible modular technologies of vocational training, retraining, and advanced training of production personnel. Career guidance must be provided to students and other population categories.

Thus, for HEls today, it is important to ensure customers' achievement of educational levels and acquisition of competencies needed for their competitiveness in the regional labor market but not just educate professions, which are in demand in the labor market. In this case, the quality of the "product of education" will meet the requirements of the "consumer" - the labor market and the employer.

\section{Materials and methods}

In 2016-2017 and 2019-2020, the authors conducted comprehensive monitoring of the compliance of educational services quality provided by vocational education institutions with the labor market demand in qualified staff, based on vocational education institutions in Ivano-Frankivsk, Lviv, and Kyiv ( $n=120$ students, 66 graduates, 90 employers). As we have determined the independence from the specialization and geographical location of VEls are the indicators for their development management. Thus, we present the findings obtained from three vocational education institutions: Ivano-Frankivsk Professional College of Restaurant Service and Tourism of the National University of Food Technologies, Lviv Vocational College of Tourism and Hotel and Restaurant Service, Kyiv Higher Vocational School of Sewing and Hairdressing Art.

The formative stage of the experiment aimed at studying the quality of educational services provided by the above VEls, which is a consequence of their sustainable development and competitiveness in the regional labor market. At this stage, the purpose of the pedagogical experiment was to implement our management technology of VEI development and assess its effectiveness and the educational services quality provided by the above VEI. The objectives of the research are as follows:

-to measure the index of employment and self-employment of graduates from vocational education institutions as an indicator of their competitiveness; 
-to establish the indicators of employers' satisfaction level with the compliance of the content of vocational education and training programs with the regional labor market requirements, as the quality indicator of educational services;

-to develop and test by experiment theory-based organizational and pedagogical conditions, the combination of which contributes to the successful interaction between VEls and employers.

The achievement of the purpose and objectives set at the formative stage of the experiment includes the following phases: preparatory, selection of indicator groups, main, and final. The preparatory phase involves determining the purpose and objectives of the formative experiment and confirming the vocational education institutions, which take part in this experiment (Ivano-Frankivsk Professional College of Restaurant Service and Tourism of the National University of Food Technologies, Lviv Vocational College of Tourism and Hotel and Restaurant Service, Kyiv Higher Vocational School of Sewing and Hairdressing Art).

Two indicator groups have been selected: the first one is "Learning and employment efficiency," and the second is "Involvement of employers in the management of VEls development." During the main phase, the formative experiment has been really conducted. The final stage involves performing the conclusive diagnostics of the competitive level of the vocational education institutions. The representativeness of the sample was ensured by a sufficient number of respondents and sample frame forming with the cluster (nested) method. It means that we have selected not individual units of the general totality but clusters (nests) of these units, i.e., focus groups (students, graduates, teaching staff, employers). Participants of focus groups were selected at random. Thus, the sample size is sufficient to obtain reliable information and suitable for its operational mathematical processing.

Ivano-Frankivsk Professional College of Restaurant Service and Tourism of the National University of Food Technologies (hereinafter - IF PC RST). As of September 1, 2020, the total number of students was 640 people. The college trains specialists for domestic and international (wholesale and retail) trade; industry (commercial departments of enterprises, companies, and holdings); non-productive sphere (service, tourism, and vacation business); business structures of banks; representative offices of foreign and the largest Ukrainian companies. A person who graduated with Junior Bachelor's (Associate) degree in the above specialties should have knowledge in basics of market economy, commercial activity, finance and accounting, commercial commodity science, basics of psychology and communication, basics of legal studies, information and computer technologies, foreign language, etc.

Let us examine the first indicator group, namely "Learning and employment efficiency." For this group, it is important to consider that the total number of students in the professional college is 640 people. In 2019, 237 graduates (47\% of the total number of students) received diplomas, 146 of which were in an integrated profession. 219 (95\%) graduates are employed, and $9(3 \%)$ are self-employed (registered as private entrepreneurs). For the second indicator group, "Involvement of employers in the management of VEls development," we survey employers who hire graduates of IF PC RST in Commercial Activity. In total, representatives of 8 companies participated: LLC "Prykarpatskyi Torhovyi Dim," hypermarket "Metro," supermarket "Furshet," supermarket "Silpo," store "Zroby Sam," restaurant "Fontush," restaurant "Nadiia," and cafe "Bize." A total of 30 respondents took part in the survey. According to the survey, $62 \%$ of employers responded "completely satisfied" with the content of vocational training programs in Commercial Activity, while the other $38 \%$ chose "partially satisfied."

Representatives of employers determined the levels of existing knowledge and skills acquired within vocational training programs. Thus, $87 \%$ of employers have noted that graduates have a high level of knowledge in such subjects as Communication Activity and Commercial Activity. As for the knowledge level of graduates in the subjects Commercial Commodity Science and Computer Technologies, $75 \%$ of respondents have considered it as sufficient. $56 \%$ of respondents have assessed the graduates' level of knowledge in the subjects Statistics and Price Setting as intermediate. The representatives of employers did not assess such subjects as Ecology, Foreign Language (English, German), Cultural Studies, and Social Studies. The survey also has shown that there is a need to 
improve the curricula of the following subjects: Company Economics and Price Setting (update content and improve methodological framework); Business Finance (complement with schemes, tables); Financial Accounting (complement the methodological framework); Market Research (bring the content into compliance with modern conditions). The employers determined the following changes in vocational training programs in Commercial Activity as sufficient: updating educational programs to the latest changes in the legal acts, including regional and variable components.

The Advisory Committee and Professional Council in the field are the ways to improve the compliance of educational programs with the labor market requirements and develop partnerships with employers. The survey of employers showed that 18 (62\%) respondents are completely satisfied, and $12(38 \%)$ are partially satisfied with their participation in the work of these institutions. As a result of this cooperation, Professional Council members made changes and suggestions in such vocational training curricula as Commercial Commodity Science and Entrepreneurial Activity. The consultations led to the improvement of learning outcomes in the following specialties: Commercial Activity, Communication Activity, Bidding Techniques, and Information Systems and Technologies.

The authors selectively surveyed 22 graduates (14 men and 8 women) to study their level of satisfaction with the compliance of vocational training programs to requirements of the regional labor market. The graduates have diplomas in Commercial Activity and are $30 \%$ of last year's graduates. Regarding the course Commercial Activity, there were not graduates who argued training programs to be irrelevant and ineffective or chose the option "Not satisfied." The study found that graduates are highly satisfied with the professional training programs in the specialty Commercial Activity. However, graduates also consider that several subjects are not necessary to work in their specialty (Table 5).

Table 5. Ranking of academic subjects according to the survey of graduates of IF PC RST of 2012

\begin{tabular}{|c|c|c|c|c|}
\hline No. & $\begin{array}{c}\text { The most necessary } \\
\text { academic } \\
\text { subjects }\end{array}$ & $\begin{array}{c}\% \\
\text { responses }\end{array}$ & $\begin{array}{c}\text { The least necessary } \\
\text { academic } \\
\text { subjects }\end{array}$ & $\begin{array}{c}\% \\
\text { responses }\end{array}$ \\
\hline 1. & Computer Hardware & 100 & Market Research & 74 \\
\hline 2. & $\begin{array}{c}\text { Basics Of Document } \\
\text { Management }\end{array}$ & 100 & Company Economics & 74 \\
\hline 3. & Physical Education & 92 & Foundations of Philosophy & 74 \\
\hline 4. & Commercial Activity & 89 & Political Economy & 68 \\
\hline 5. & Legal Science & 87 & Mathematics & 56 \\
\hline
\end{tabular}

Source: compiled by authors.

Lviv Vocational College of Tourism and Hotel and Restaurant Service (hereinafter - LVC THRS) is the vocational education institution of sustainable development, which primarily aims at training an innovative, competitive specialist in the hospitality and tourism industry in the domestic and international markets. The vocational education institution provides students with complete general secondary education, pre-vocational education, and incomplete higher education. It trains highly qualified workers in the following professions: cook, confectioner; cook, waiter; cook (a dual mode of education); cook, pizza chef; waiter, administrator; specialist in restaurant service; specialist in hotel service; tourism agent, administrator; food seller, supply agent. Moreover, the vocational education institution also trains junior specialists in food technology, tourism, entrepreneurship, trade, and exchange activities.

For the first indicator group, namely "Learning and employment efficiency," it is important to consider that the total number of students was 1,020 people as of September 1,2020. For the second indicator group, we survey employers who hire graduates of LPC HTRS in Commercial Activity. In total, the participants were the representatives of 5 companies, namely: LLC TM "Barvinok," PE "ZorepadLiuks," PE "Morozov M.Yu.," Regional Office "Zakhid Yevrotek," and LLC "Fozzy." A total of 30 respondents took part in the survey. According to the survey, 24 (80\%) employers responded "completely satisfied" with the content of vocational training programs in Commercial Activity, while the other $6(20 \%)$ chose "partially satisfied." The representatives of employers did not assess such 
subjects as Ecology, Foreign Language (English, German), Health and Safety, Social Studies, and Statistics. The results of the survey have shown that the following academic subjects need to be improved: Commercial Activity and Accounting (update content and improve methodological framework); Business Finance (complement with schemes, tables); International Economic Activity (complement the methodological framework); Information Systems and Technologies (bring the content into compliance with modern conditions).

The authors selectively surveyed 22 graduates to study their level of satisfaction with the relevance and efficiency of the course program Commercial Activity. The respondents make 30\% of last year's graduates. 14 (63.6\%) graduates responded "completely satisfied" with the relevance and efficiency of the course program Commercial Activity, while the other $4(18,2 \%)$ chose "partially satisfied." Regarding the course Commercial Activity, there were not graduates who argued the course program to be irrelevant and ineffective or chose the option "Not satisfied." The study found that graduates are highly satisfied with the professional training programs in the specialty Commercial Activity. However, graduates also consider that several subjects are not necessary to work in their specialty (Table 6).

Table 6. Ranking of academic subjects according to the survey of graduates of LVC THRS of 2020

\begin{tabular}{|c|c|c|c|c|}
\hline No. & $\begin{array}{c}\text { The most necessary academic } \\
\text { subjects }\end{array}$ & $\begin{array}{c}\% \\
\text { Responses }\end{array}$ & $\begin{array}{c}\text { The least necessary } \\
\text { academic } \\
\text { subjects }\end{array}$ & $\begin{array}{c}\% \\
\text { Responses }\end{array}$ \\
\hline 1. & $\begin{array}{c}\text { Informatics and Computer } \\
\text { Hardware }\end{array}$ & 100 & $\begin{array}{c}\text { Commodity market } \\
\text { infrastructure }\end{array}$ & 65 \\
\hline 2. & Business Economics & 100 & Political Economy & 60 \\
\hline 3. & $\begin{array}{c}\text { Foreign Language (for Special } \\
\text { Purposes) }\end{array}$ & 90 & Foundations of Philosophy & 60 \\
\hline 4. & Business Finance & 90 & Social Studies & 50 \\
\hline 5. & Entrepreneurial Activity & 80 & Statistics & 50 \\
\hline
\end{tabular}

Source: compiled by authors.

The employers determined the following changes in vocational training programs in Commercial Activity as sufficient: increasing the number of laboratory and practical classes, implementing the everyday goods research, and carrying out examinations.

In LVC THRS, Logistics was introduced as a new academic subject. It will promote students' deep knowledge of the concept, strategy, and tactics of logistics. With the help of this academic subject, students will be able to master logistics thinking skills, make suggestions for improving logistics systems, and assess the cost-effectiveness of logistics decisions. LVC THRS has improved several academic subjects, namely Commercial Activity within the Training Company, Marketing, and Ethics. Commercial Activity within the Training Company involves the following: developing abilities within the information analysis and determination of work purposefulness; developing students' creative activity and initiative; critical thinking; analysis of problems and ways to solve them; consolidation of knowledge in solving practical problems in vocational training; developing practical skills at the workplaces of the training company; performing trade and technological operations at the wholesale enterprise and their documentation.

Marketing as an academic subject involves the following: acquiring practical skills to solve specific problems in marketing and developing skills of a creative search for improvement opportunities of enterprise marketing. Ethics will help students to develop a system of knowledge in general, labor and communication psychology, and business etiquette, assess the objective reality, and find optimal solutions in specific situations using interactive teaching methods.

The Advisory Committee and Professional Council in the field contributed to the improvement of educational programs. The survey of employers showed that $62 \%$ of respondents are completely satisfied, and $38 \%$ of them are partially satisfied with their participation in the work of these institutions. As a result of this cooperation, Professional Council members made changes and suggestions in such vocational training curriculum as Basics of Market Research. The consultations led 
to the improvement of learning outcomes in the following specialties: Foreign Language for Specific Purpose, Communication Activity, and Commercial Activity.

Kyiv Higher Vocational School of Sewing and Hairdressing Art (hereinafter - KHVS SHA) is a stateowned, vocational education institution that trains workers for sewing and hairdressing enterprises, food industry, and commercial structures, etc. KHVS SHA trains skilled workers in the following professions: tailor, cutter; embroiderer, tailor; hairdresser (hair stylist), cook, confectioner; typesetting operator (accountant for registration of accounting data). In 2020, the higher vocational school received a license to train junior bachelors in the following specialties: Design. Hairdressing and Makeup (25 people); Light Industry Technologies. Modeling and Design of Industrial Products (30 people). As of January 1, 2021, the number of students for state-funded education is 820 people.

Let us examine the first indicator group, namely "Learning and employment efficiency." For this group, it is important to consider that the total number of students was 820 people as of September $1,2020.262$ graduates ( $100 \%$ of the total number of students) received diplomas, 122 of which were in an integrated profession. $242(92,4 \%)$ graduates are employed, and $7,6 \%$ of graduates are unemployed due to such reasons as maternity leave and leave for childcare. 12 people registered as a natural person-entrepreneur. For the second indicator group, we survey employers who hire graduates of KHVS SHA in Food Technologies. In total, representatives of 10 companies participated: LLC restaurant "Ani," restaurant "El Pation," PE "Ukrainski Stravy," PRAT "Shvydko-Ukraina," restaurant chain "Myrova Karta," cafe "Stena," LLC "Restaurant Panas," PE "Puzata Khata," supermarket "Furshet," supermarket "Silpo." A total of 30 respondents took part in the survey. According to the survey, 14 (42\%) employers responded "completely satisfied," 7 (21\%) and $9(27 \%)$ of respondents chose "satisfied" and "partially satisfied" with the compliance of the level of graduates' competence with the requirements of the regional labor market.

Representatives of employers determined the levels of existing knowledge and skills acquired within vocational training programs. Thus, employers have noted that graduates have a high level of knowledge in the following subjects: Organization of Production and Service (70\% of respondents); Food Technologies with the Basics of Commodity Science, (65\% of respondents); Equipment of Catering and Commercial Commodity Science ( $55 \%$ of respondents). The representatives of employers did not assess such subjects as Ecology, Physical Education, Health and Safety, Social Studies, and Statistics. The survey also has shown that the following subjects need improvement: Nutrition Psychology (update content and improve methodological framework); Accounting, Calculation, and Reporting (complement with schemes, tables); Labor Protection (bring the content into compliance with modern conditions); Food Technologies with the Basics of Commodity Science (update content and complement the methodological framework).

Table 7. Ranking of academic subjects according to the survey of graduates of KHVS SHA of 2019-2020

\begin{tabular}{|c|c|c|c|c|}
\hline No. & $\begin{array}{c}\text { The most necessary academic } \\
\text { subjects }\end{array}$ & $\begin{array}{c}\% \\
\text { the } \\
\text { answers }\end{array}$ & $\begin{array}{c}\text { The least necessary } \\
\text { academic subjects }\end{array}$ & \% Responses \\
\hline 1. & $\begin{array}{c}\text { Food Technologies with the } \\
\text { Basics of Commodity Science }\end{array}$ & 100 & $\begin{array}{c}\text { Basics of Document } \\
\text { Management }\end{array}$ & 42 \\
\hline 2. & $\begin{array}{c}\text { Organization of Production and } \\
\text { Service }\end{array}$ & 100 & Basics of Statistics & 45 \\
\hline 3. & Equipment of Catering & 90 & Business Economics & 48 \\
\hline 4. & $\begin{array}{c}\text { Accounting, Calculation, and } \\
\text { Reporting }\end{array}$ & 90 & Fundamentals of Ecology & 52 \\
\hline 5. & Foreign Language & 85 & Political Economy & 58 \\
\hline
\end{tabular}

Source: compiled by authors.

The authors conducted a telephone survey of 22 graduates of KHVS SHA. Regarding the relevance and effectiveness of training programs in the specialty Cook, the survey showed that $11(50 \%)$ respondents are completely satisfied, $9(42 \%)$ - satisfied, and $2(8 \%)$ - partially satisfied. The study 
found that graduates are highly satisfied with the professional training programs in specialty Food Technologies. However, graduates also consider that several subjects are not necessary to work in their specialty (Table 7).

The Advisory Committee and Professional Council in the field are the ways to improve the compliance of educational programs with the labor market requirements and develop partnerships with employers. The survey of employers showed that 20 (68\%) respondents are completely satisfied, and $10(32 \%)$ are partially satisfied with their participation in the work of these institutions. As a result of this cooperation, Professional Council members made changes and suggestions in such a vocational training curriculum as Food Technologies with the Basics of Commodity Science. The consultations led to the improvement of learning outcomes in the following specialties: Equipment of Catering and Accounting, Calculation, and Reporting.

\section{Results}

The final phase of the experiment involves a comparison of diagnostic results (2019-2020). To the results of the final phase of the experiment, we include the following: the comparison of dynamics of VEls development; determination by the teaching staff of directions and individual trajectories of further professional training; the transition of the pedagogical research findings in the institutionalization mode (permanent search and experimental vocational education systems); auditing the effectiveness of the implemented conceptual model of managing the VEls development and management technologies; analysis and generalization of achievements and ways to obtain them in management of VEls teaching staff; development of recommendations to distribute and apply the positive experience in the management of VEls growth; preserving positive achievements of the teaching staff of VEls in the maintenance of competitiveness and correction of the revealed shortcomings.

In the study, the authors used pedagogical tools to fulfill the set objectives, namely: clarifying interview, interview, rating, competitions for the professional skill of different levels, methodical seminars, etc. The rating table below shows the extent to which the students and graduates recognize that the academic subjects comply with the labor market requirements in 2019-2020. Among the most necessary, respondents name the following subjects: Computer Technologies, Business Finance, Commercial Activity, and Foreign Language. This confirms the global trends in vocational education and training (Table 8, Figure 1).

Table 8. Indicators of employers' satisfaction level with the compliance of vocational training programs to the requirements of the regional labor market in 2020

\begin{tabular}{|c|c|c|c|c|c|}
\hline \multirow[t]{2}{*}{ No. } & \multirow{2}{*}{$\begin{array}{l}\text { Indicators of knowledge and skills } \\
\text { level }\end{array}$} & \multirow[t]{2}{*}{ Response option } & $\begin{array}{l}\text { IF PC } \\
\text { RST }\end{array}$ & $\begin{array}{l}\text { LVC } \\
\text { THRS }\end{array}$ & $\begin{array}{l}\text { KHVS } \\
\text { SHA }\end{array}$ \\
\hline & & & $\%$ & $\%$ & $\%$ \\
\hline 1 & High & Completely satisfied & 62 & 80 & 42 \\
\hline 2 & Sufficient & Satisfied & 36 & 12 & 21 \\
\hline 3 & Medium & Partly satisfied & 12 & 8 & 27 \\
\hline 4 & Low & $\begin{array}{l}\text { Completely } \\
\text { dissatisfied }\end{array}$ & 0 & 0 & 0 \\
\hline
\end{tabular}

Source: compiled by authors. 
Figure 1. Indicators of employers' satisfaction level with the compliance of vocational training programs to the requirements of the regional labor market in 2020

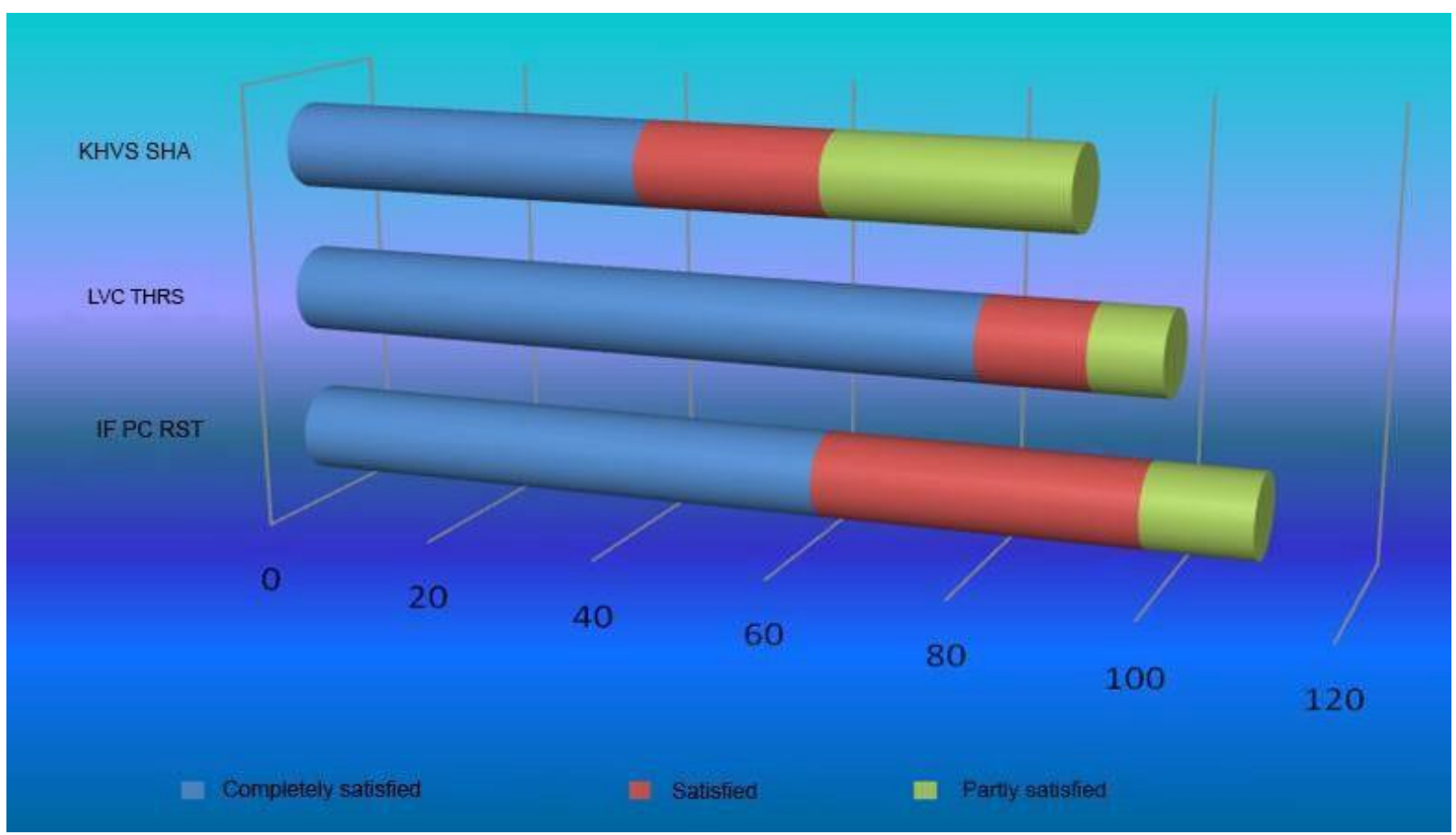

Source: compiled by authors.

The authors carried out the diagnostics of educational services quality through questionnaires, interviews, qualimetric outcome evaluation of a sample survey of students, graduates, employers, teaching staff. The study compared diagnostic results of 2020 by 2 groups of indicators: "Learning and employment efficiency" and "Involvement of employers in the management of VEls development." The authors also examined the following: employment and self-employment level among VEls graduates (Table 9, Figure 2); satisfaction of graduates with the relevance and effectiveness of vocational training programs; employers' satisfaction with the level of vocational education and training programs for graduates; employers' satisfaction with the cooperation of enterprises and vocational education institutions (Table 10, Figure 3).

Table 9. Employment and self-employment indicators of VEls graduates in 2019-2020

\begin{tabular}{|c|c|c|c|c|c|c|c|c|c|}
\hline \multirow{2}{*}{ Indicator } & \multicolumn{3}{|c|}{ IF PC RST } & \multicolumn{3}{c|}{ LVC THRS } & \multicolumn{3}{c|}{ KHVS SHA } \\
\cline { 2 - 11 } & Total & Employed & $\begin{array}{c}\text { Self- } \\
\text { employed }\end{array}$ & Total & Employed & $\begin{array}{c}\text { Self- } \\
\text { employed }\end{array}$ & Total & Employed & $\begin{array}{c}\text { Self- } \\
\text { employed }\end{array}$ \\
\hline Graduates & 337 & 309 & 9 & 515 & 453 & 15 & 262 & 242 & 12 \\
\hline$\%$ & 100 & 95 & 3 & 100 & 88 & 3.3 & 100 & $92.4 \%$ & 4.6 \\
\hline
\end{tabular}

Source: compiled by authors.

Figure 2. Employment and self-employment indicators of VEls graduates in 2019-2020

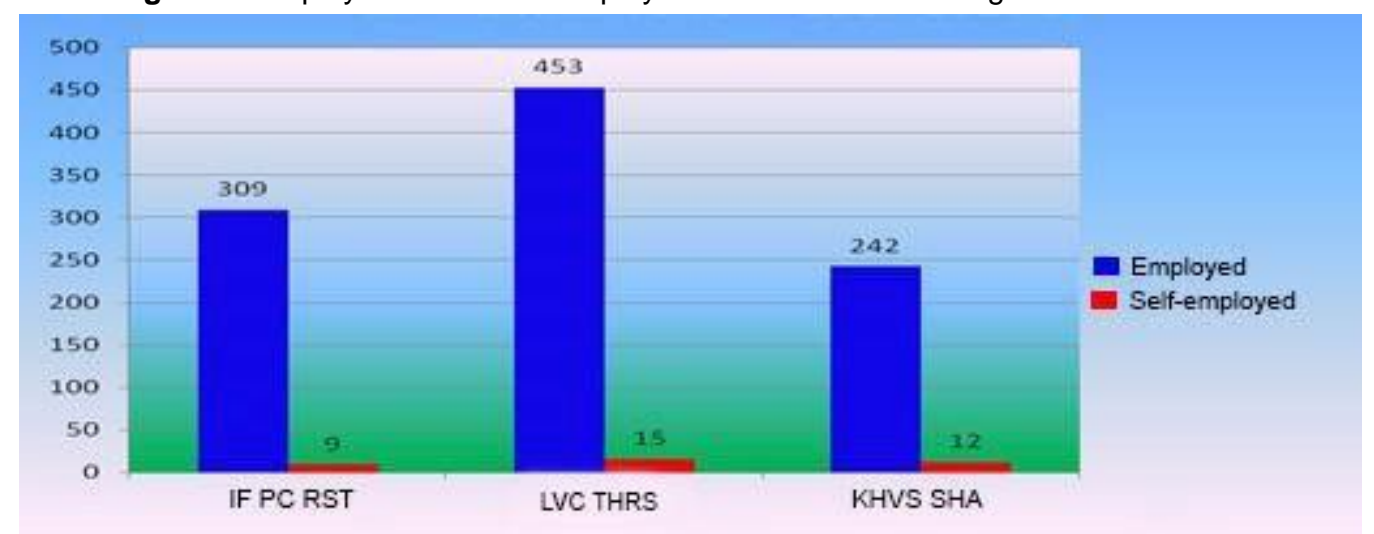

Source: compiled by authors. 
Larysa M. Sergeieva, Vira V. Hriadushcha, Gennadii O. Dubov, Taras O. Didych, Maryna I. Saienko

Table 10. Indicators of satisfaction level of VEls graduates with the relevance and effectiveness of vocational training programs in 2020

\begin{tabular}{|c|c|c|c|c|c|c|c|}
\hline \multirow{2}{*}{ Indicator } & \multirow{2}{*}{$\begin{array}{c}\text { Response } \\
\text { option }\end{array}$} & \multicolumn{2}{|c|}{ IF FC RST } & \multicolumn{2}{|c|}{ LVC THRS } & \multicolumn{2}{|c|}{ KHVS SHA } \\
\hline & & total & $\%$ & total & $\%$ & total & $\%$ \\
\hline High & $\begin{array}{c}\text { Completely } \\
\text { satisfied }\end{array}$ & 13 & 66 & 14 & 63.6 & 11 & 50 \\
\hline Sufficient & Satisfied & 7 & 26 & 4 & 18.2 & 9 & 42 \\
\hline Medium & $\begin{array}{c}\text { Partly } \\
\text { satisfied }\end{array}$ & 2 & 16 & 4 & 18.2 & 2 & 8 \\
\hline Low & $\begin{array}{l}\text { Completely } \\
\text { dissatisfied }\end{array}$ & 0 & 0 & 0 & 0 & 0 & 0 \\
\hline
\end{tabular}

Source: compiled by authors.

Figure 3. Satisfaction of VEls graduates with the effectiveness of vocational training programs

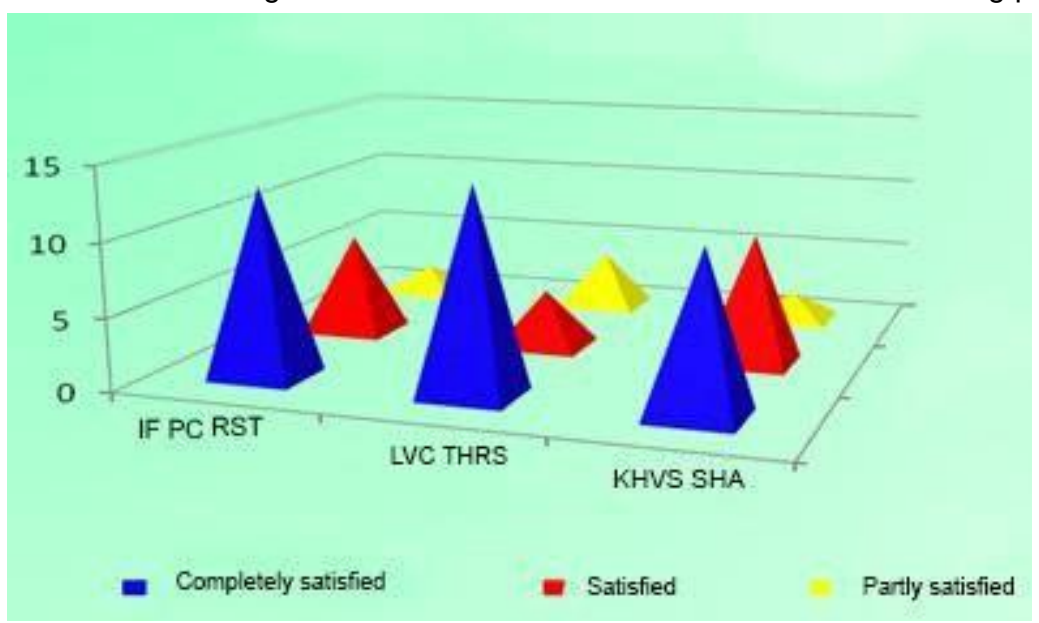

Source: compiled by authors.

In the course of scientific research, we measured the effectiveness of vocational education institutions according to the indicators:

1) learning and employment efficiency;

2) involvement of employers;

$K_{1}$ - quantitative coefficient of employment quality of VEls graduates:

$$
K_{1}=\frac{N_{1}}{n_{1}}
$$

where $\mathrm{N}_{1}$ - number of employed graduates of VEls in 2020,

$\mathrm{n}_{1}$ - the number of employed graduates of VEls in 2016.

Thus,

$$
K_{1}=\frac{1050}{876}=1.9
$$

where $K_{2}$ - quantitative coefficient of self-employment of VEls graduates:

$$
K_{2}+=\frac{N_{2}}{n_{2}}
$$

where $\mathrm{N}_{2}$ - the number of self-employed graduates of VEls in 2020,

$\mathrm{n}_{2}$ - the number of self-employed graduates of VEls in 2016. 


$$
K_{2}=\frac{40}{7}=5.7
$$

where $\mathrm{K}_{3}$ - quantitative coefficient of quality of VEls graduates who have received an integrated profession.

$$
K_{3}=\frac{N_{3}}{n_{3}}
$$

where $N_{3}$ - the number of VEls graduates who received an integrated profession in 2020,

$n_{3}$ - the number of VEls graduates who received an integrated profession in 2016.

$$
K_{3}=\frac{542}{293}=1.8
$$

where $\mathrm{K}_{4}$ - quantitative coefficient of employers' satisfaction with the compliance of vocational training programs to the labor market requirements

$$
K_{4}=\frac{N}{n_{4}},
$$

where $N_{4}$ - the number of employers satisfied with the compliance of vocational training programs to the labor market requirements in 2020.

$n_{4}$ - the number of employers satisfied with the compliance of vocational training programs to the labor market requirements in 2016.

$$
K_{4}=\frac{57}{34}=1.7
$$

where $\mathrm{K}_{5}$ - quantitative coefficient of satisfaction of VET graduates with the compliance of vocational training programs with the requirements of the labor market.

$$
K_{5}=\frac{N_{5}}{n_{5}}
$$

where $N_{5}-$ the number of VET graduates satisfied with the compliance of vocational training programs with the requirements of the labor market in 2020.

$n_{5}-$ the number of employers satisfied with the compliance of vocational training programs with the requirements of the labor market in 2016.

$$
K_{5}=\frac{40}{28}=1.5
$$

where $\mathrm{K}_{6}$ - quantitative coefficient of satisfaction with the cooperation between vocational education institutions and employers.

$$
K_{6}=\frac{N_{6}}{n_{6}},
$$


where $N_{6}-$ the number of employers satisfied with the cooperation with VEls in 2020.

$n_{6}{ }^{-}$the number of employers satisfied with the cooperation with VEIs in 2016.

$$
K_{6}=\frac{57}{27}=2.1
$$

Quality coefficient:

$$
\bar{K}=\frac{\sum_{i-1}^{n} K i}{n}
$$

where $\mathrm{n}$ is the total number of coefficients,

$$
\bar{K}=\frac{1.9+5.7+1.8+1.7+1.5+2.1}{6}=2.45
$$

The quality coefficient of VEls activity measured by groups of indicators confirms the correctness of the scientific research and formative experiment since the average quality coefficient of vocational education institutions in 2020 is 2.45 times more than in 2016. The positive dynamics of VEls development confirm our assumptions about the expediency of the conceptual model of managing the VEls development, which we see as an open, dynamic system capable of updating and accepting

\begin{tabular}{|c|c|c|c|c|c|c|c|c|c|}
\hline \multirow[t]{2}{*}{ No. } & \multirow[b]{2}{*}{ Indicator } & \multicolumn{4}{|c|}{ 2016-2017 } & \multicolumn{4}{|c|}{ 2019-2020 } \\
\hline & & $\begin{array}{l}\text { IF PC } \\
\text { RST }\end{array}$ & $\begin{array}{l}\text { LVC } \\
\text { THRS }\end{array}$ & $\begin{array}{l}\text { KHVS } \\
\text { SHA }\end{array}$ & $\Sigma$ & $\begin{array}{l}\text { IF PC } \\
\text { RST }\end{array}$ & $\begin{array}{l}\text { LVC } \\
\text { THRS }\end{array}$ & $\begin{array}{l}\text { KHVS } \\
\text { SHA }\end{array}$ & $\Sigma$ \\
\hline I & \multicolumn{9}{|c|}{ Learning and employment efficiency } \\
\hline 1.1 & Employed & 241 & 326 & 309 & 876 & 309 & 489 & 241 & 1050 \\
\hline 1.2 & Self-employed & 3 & 2 & 2 & 7 & 9 & 20 & 11 & 40 \\
\hline 1.3 & $\begin{array}{l}\text { Received an } \\
\text { integrated profession }\end{array}$ & 86 & 117 & 90 & 293 & 146 & 274 & 122 & 542 \\
\hline II & \multicolumn{9}{|c|}{ Involvement of employers } \\
\hline 2.1 & $\begin{array}{l}\text { Compliance of } \\
\text { programs with the } \\
\text { labor market } \\
\text { requirements }\end{array}$ & 14 & 12 & 8 & 34 & 19 & 24 & 14 & 57 \\
\hline 2.2 & $\begin{array}{l}\text { Graduates' } \\
\text { satisfaction with the } \\
\text { content of } \\
\text { educational programs }\end{array}$ & 11 & 7 & 10 & 28 & 13 & 14 & 13 & 40 \\
\hline 2.3 & Level of cooperation & 8 & 6 & 7 & 27 & 18 & 19 & 20 & 57 \\
\hline
\end{tabular}
change.

Table 11. Comparative results of the experiment by indicator groups

Having analyzed the problem existing in the theory and practice of the management of vocational education institutions, the authors argue that the compliance of the quality of educational services provided by these institutions with the regional labor market demands is given insufficient attention. This negatively affects the qualified staff training for industries. The modern vocational education institution is an open socio-pedagogical system, which interacts with many economic and social institutions. The activity of vocational education institutions affects all spheres of society and creates many positive externalities, which drive the social and economic development of the country. When the sphere of educational services is developing, functioning, and receiving investments, it causes 
benefits not only for the employee and his employer but also for third parties and has a positive, uncompensated impact. It is felt by at least the immediate environment of the educational service recipient.

The quality of staff vocational training becomes especially important under a market economy. It represents a necessary factor in production profitability and determines the competitiveness of the enterprise. It is established that the segmentation of the regional labor market is an important tool for strategic planning of VEls activities and becomes the basis in the competition between these vocational education institutions for entrants (Table 11).

Forecasting the development of the labor market is an important tool for active interaction between VEls and social partners. The involvement of representatives of industries and enterprises in curriculum development ensures compliance of vocational training with the regional labor market requirements. The survey of graduates and students of 2016-2017 and 2019-2020 has allowed rating academic subjects, which primarily meet the demands of employers (Table 12).

Table 12. Ranking table of compliance of academic subjects with labor market requirements

\begin{tabular}{|c|c|c|c|c|}
\hline Rating & Year & IF PC RST & LVC THRS & KHVS SHA \\
\hline \multirow{2}{*}{1} & $\begin{array}{l}2016- \\
2017\end{array}$ & $\begin{array}{c}\text { Computer } \\
\text { Technologies }\end{array}$ & Commercial Activity & $\begin{array}{l}\text { Food Technologies with the } \\
\text { Basics of Commodity Science }\end{array}$ \\
\hline & $\begin{array}{l}2019- \\
2020\end{array}$ & $\begin{array}{c}\text { Computer } \\
\text { Technologies }\end{array}$ & $\begin{array}{c}\text { Informatics and } \\
\text { Computer Hardware }\end{array}$ & $\begin{array}{l}\text { Food Technologies with the } \\
\text { Basics of Commodity Science }\end{array}$ \\
\hline \multirow[b]{2}{*}{2} & $\begin{array}{l}2016- \\
2017\end{array}$ & Legal Science & $\begin{array}{c}\text { Basics Of Document } \\
\text { Management }\end{array}$ & Equipment of Catering \\
\hline & $\begin{array}{l}2019- \\
2020\end{array}$ & $\begin{array}{c}\text { Basics Of } \\
\text { Document } \\
\text { Management }\end{array}$ & Business Economics & $\begin{array}{c}\text { Organization of Production } \\
\text { and Service }\end{array}$ \\
\hline \multirow{2}{*}{3} & $\begin{array}{l}2016- \\
2017\end{array}$ & $\begin{array}{l}\text { Commercial } \\
\text { Activity }\end{array}$ & Computer Technologies & $\begin{array}{c}\text { Hygiene and Sanitation of } \\
\text { Enterprise }\end{array}$ \\
\hline & $\begin{array}{l}2019- \\
2020\end{array}$ & Physical Education & Foreign Language & Food business equipment \\
\hline \multirow{2}{*}{4} & $\begin{array}{l}2016- \\
2017\end{array}$ & Foreign Language & $\begin{array}{l}\text { Basics of Market } \\
\text { Research }\end{array}$ & $\begin{array}{l}\text { Organization of production } \\
\text { and service }\end{array}$ \\
\hline & $\begin{array}{l}2019- \\
2020\end{array}$ & $\begin{array}{c}\text { Commercial } \\
\text { Activity }\end{array}$ & Business Finance & $\begin{array}{l}\text { Accounting, Calculation, and } \\
\text { Reporting }\end{array}$ \\
\hline \multirow[t]{2}{*}{5} & $\begin{array}{l}2016- \\
2017\end{array}$ & $\begin{array}{c}\text { Basics Of } \\
\text { Document } \\
\text { Management }\end{array}$ & Foreign Language & $\begin{array}{c}\text { Accounting, Calculation, and } \\
\text { Reporting }\end{array}$ \\
\hline & 2012 & Legal Science & Entrepreneurial Activity & Foreign Language \\
\hline
\end{tabular}

Source: compiled by authors.

It is appropriate to organize Advisory Committees and Professional Councils in VEls as an innovative form of interaction between vocational education institutions and employers in the professional educational environment. The research confirmed the need for additional scientific studies of the problem in management and promotion of the educational services quality provided by vocational education institutions to the labor market demands in qualified staff. Thus, the main purpose of the VEI, no matter of ownership, is to provide conditions for training professionals for the state's needs. The vocational training must be based on the following principles: accessibility for all citizens of all forms and types of educational services, equal conditions, humanism, flexibility, and continuity of education. On the other hand, VEls function as a rightful entity of the educational services market, and that entails a high degree of competitiveness in the vocational education system.

Competitive requirements for the management system of vocational education institutions prove the need for its modernization. The modernization will ensure the adaptation to modern economic and social conditions and determine strategic guidelines for future development. Special attention is 
given to the issues of social and economic efficiency of the whole vocational education system, its separate institutions, and especially VEls, which are the objects of corporate governance. We believe the management science and economic practice are primarily aimed to establish effective mechanisms for VEls corporate governance, regulate their development under the needs of the regional labor market, and increase competitiveness.

\section{Conclusions}

The study of the compliance of the educational services market with the labor market needs, taking into account the balance between supply and demand for labor, allowed the authors to identify priority areas for innovative management of the activity. The main vectors for the innovative development of VEls are the introduction and development of new educational programs, innovations, and educational marketing. During the research, the authors also determined the following: main trends in the quality improvement of educational services provided by vocational education institutions to the labor market demand in qualified personnel; the increased segment of distance education; introduction of ICT; deep integration of industrial training process with production technologies at enterprises; conducting masterclasses and introducing modern forms of proficiency enhancement of future professionals; improving the work experience internship, the content of which is agreed with employers. The authors searched for new progressive forms of involvement of stakeholders in the management of VEls development. These forms are associated with changing stereotypes, focusing on social and economic realities of the labor market, modern world trends, taking into account the features of national development.

\section{Acknowledgements}

The results of the scientific search were obtained in accordance with the topic of research work "Transformation of vocational development of specialists in the Open University of Postgraduate Education" (registration number 0120U104637, registration date 30.10.2020) and in pursuance of the Order of the Ministry of Education and Science of Ukraine, No. 23, as of January 9, 2020, On conducting a pedagogical experiment at the national level on the topic "Formation of entrepreneurial competence of future skilled service workers within vocational training" in 2019-2023.

\section{References}

1. Anishchenko, V.M., Zakatnov, D.O., Zdioruk, S.I., Klepko, S.F., \& Radkevich, V.O. (2012). Directions of reforming the system of vocational education in the context of European integration (experience, analysis, forecasts). Kyiv: Pedahohichna dumka.

2. Cabinet of Ministers of Ukraine. (2019). Concept of realization of the state policy in the field of professional (vocational) education "Modern professional (vocational) education" for the period till 2027. Retrieved from https://zakon.rada.gov.ua/laws/show/419-2019-\%D1\%80\#Text

3. Carpio, X., Merchant, O., Mueller, N., \& Olefir, A. (2017). Skills for modern Ukraine. Retrieved from https://openknowledge.worldbank.org/bitstream/handle/10986/25741/210890ovUK.pdf?sequen ce $=5$

4. Institute of Vocational Education of the National Academy of Pedagogical Sciences of Ukraine. (2021). Retrieved from https://ivet.edu.ua/activity/ndr

5. Kosiv, L. (2003). How to find staff for the company. Youth and Entrepreneurship: All-Ukrainian Youth Journal, 7, 34-38.

6. Kozlovskyi, S., Butyrskyi, A., Poliakov, B., Bobkova, A., Lavrov, R., \& Ivanyuta, N. (2019). Management and comprehensive assessment of the probability of bankruptcy of Ukrainian enterprises based on the methods of fuzzy sets theory. Problems and Perspectives in Management, 17(3), 370-381. doi:10.21511/ppm.17(3).2019.30

7. Krushelnytska, O.V., \& Melnychuk, D.P. (2005). Personnel management: textbook. Kyiv: Condor. 
8. Schwab, K. (2019). The fourth industrial revolution. Shaping the fourth industrial revolution. Kharkiv: Klub Simeynoho Dozvillya.

9. State Employment Center of Ukraine. (2021). Retrieved from https://www.dcz.gov.ua/analitics/69

10.State Institute for Family and Youth Policy. (2020). Youth in the labor market: 21st century skills and career building. Retrieved from: https://dismp.gov.ua/dopovid-m2019/

11.State Statistics Service. (2021). Demographic and social statistics / Labor market / Employment and unemployment. Retrieved from: http://www.ukrstat.gov.ua/operativ/menu/menu_u/rp.htm

12.Sydorenko, V. (2020a). Self-coaching (self-tutoring) as a technology of professional development of a teacher of the New Ukrainian school: special course. Kyiv: Agroosvita.

13.Sydorenko, V. (2020b). Soft skills as an educational trend and a necessary development component for a vocational lifelong education teacher. Fundamental and Applied Researches in Practice of Leading Scientific Schools, 38(2), 127-134.

14.Sydorenko, V., Shorobura, I., Ponomarenko, A., Dei, M., \& Dzhus, O. (2020). Application of technologies of formal and non-formal education for continuous professional development of the modern specialist. Revista Tempos E Espaços Em Educação, 13(32), 1-24.

15.The UN General Assembly. (2015). Transforming our world: the 2030 Agenda for Sustainable Development. Retrieved from

https://www.un.org/en/development/desa/population/migration/generalassembly/docs/globalc ompact/A_RES_70_1_E.pdf

16.Ukrinform. (2019). Expert: $44 \%$ of university graduates work outside the profession. Retrieved from https://www.ukrinform.ua/rubric-society/2737000-ekspert-44-vipusknikiv-visiv-pracuut-ne-zafahom.html

17.Verkhovna Rada of Ukraine. (2010). About Recommendations of parliamentary hearings "Strategy of innovative development of Ukraine for 2010-2020 in the conditions of globalization challenges". Retrieved from: http://zakon1.rada.gov.ua/cgi-bin/laws/main.cgi?nreg=2632-17

18. Word and deed. (2021). Where do Ukrainians work and how much do they earn in different spheres of employment. Retrieved from:

https://www.slovoidilo.ua/2021/03/31/infografika/suspilstvo/pracyuyut-ta-skilky-otrymuyutukrayinczi-riznyx-sferax-zajnyatosti

19.World Economic Forum. (2020). The future of jobs report 2020. Retrieved from: http://www3.weforum.org/docs/WEF_Future_of_Jobs_2020.pdf

20.Yaroshenko, O. M., Vapnyarchuk, N. M., Lozovoi, S. V., Yakovleva, G. O., \& Yakovlyev, O. A. (2018). General-compulsory medical insurance: World experience. Journal of Advanced Research in Law and Economics, 9(5), 1829-1838. 